\title{
Feasibility of gene therapy in Gaucher disease using an adeno-associated virus vector
}

Received: 26 May 2004 / Accepted: 5 July 2004 / Published online: 14 September 2004

(C) The Japan Society of Human Genetics and Springer-Verlag 2004

\begin{abstract}
Gaucher disease, one of the common lysosomal storage disorders, is caused by a deficiency of glucocerebrosidase (GC). We investigated gene transfer using recombinant adeno-associated viral (rAAV) vectors containing human GC cDNA driven by the human elongation factor $1-\alpha$ promoter. This rAAV vector mediated efficient expression of human GC in human Gaucher fibroblasts. GC activities were increased from 2.8 to 3.4 times in normal fibroblast and from 1.9 to 4.6 times in Gaucher fibroblasts, and these increases in GC activity were maintained over 20 weeks. Intravenous administration of vectors via the hepatic portal vein and tail vein of wild-type mice resulted in efficient transduction into the tissues. GC activities of the liver, spleen, and lung in transduced mice were increased significantly up to two fold at 6 weeks after transduction. Significantly increased GC activities persisted over 20 weeks. Therefore, rAAV vector-mediated gene transfer may provide a therapeutic approach for the treatment of Gaucher disease.
\end{abstract}

Y. B. Hong $\cdot$ E. Y. Kim · S.-C. Jung $(\bowtie)$

Division of Genetic Disease,

Department of Biomedical Sciences,

National Institute of Health,

5 Nokbun-Dong, Eunpyung-Gu, Seoul

122-701, South Korea

E-mail: jungsc@ewha.ac.kr

Tel.: + 82-2-26505724

Fax: + 82-2-26527846

H.-W. Yoo

Department of Pediatrics,

Medical Genetics Clinic and Laboratory,

Asan Medical Center,

University of Ulsan College of Medicine,

Seoul, South Korea

S.-C. Jung

Department of Biochemistry,

College of Medicine,

Ewha Womans University,

Seoul, South Korea
Keywords Gaucher disease - Glucocerebrosidase •

Adeno-associated virus · AAV vector · Gene therapy

\section{Introduction}

Gaucher disease (OMIM 230800, 230900, 231000) is a lysosomal storage disorder in which deficient glucocerebrosidase (D-glucosyl- $N$-acylsphingosine glucohydrolase, EC 3.2.1.45; GC) activity causes glucocerebroside to accumulate in the lysosomes of cells of the monocyte/ macrophage system, largely in the spleen and liver (Brady et al. 1966; Beutler and Grabowski 2001). Clinically, patients with Gaucher disease are divided into three major phenotypes: chronic nonneuronopathic (type I), acute neuronopathic (type II), and chronic neuronopathic (type III), based on symptoms of the nervous system as well as the severity and age of disease onset (Brady et al. 1993).

Enzyme replacement therapy (ERT) is now the standard treatment for Gaucher disease (Kornfeld and Mellman 1989; Barton et al. 1990); however, it is very expensive to administer biweekly infusions of the recombinant enzyme throughout the life of the patients. Another therapeutic option is to decrease the synthesis of glucosylceramide using inhibitors of ceramide glucosyltransferase (substrate depletion therapy), but this strategy appears to be more toxic and somewhat less effective than ERT (Cox et al. 2000).

A special feature of the hydrolytic enzymes in lysosomal storage disorders is that they are secreted rather than trafficked directly to lysosomes (von Figura and Hasilik 1986; Dahms et al. 1989). However, these secreted enzymes can be recaptured via the mannose-6-phosphate receptors by adjacent and distant cells known as receptor-mediated endocytosis (von Figura and Hasilik 1986; Dahms et al. 1989; Neufeld 1991). Receptor-mediated endocytosis can be a great advantage for virus vector-mediated gene delivery as well as ERT (Barton et al. 1991; Grabowski et al. 
1995). In virus vector-mediated gene delivery, genecorrected cells could secrete the correct enzyme for adjacent and distant cells, and this mechanism may lower the proportion of target cells that must be corrected to obtain clinical efficacy.

To address the therapeutic efficacy of virus vectormediated gene delivery, we evaluated the use of recombinant adeno-associated virus (rAAV), which has been used extensively as a potential vehicle for gene delivery (Nakai et al. 2000; Wang et al. 2000). rAAV is a helper-dependent human parvovirus that requires coinfection with an adenovirus or herpesvirus for replication and viral assembly, and it is a singlestranded DNA virus that is nonpathogenic. rAAV is capable of efficient and prolonged transgene expression in both dividing and nondividing cells with no apparent adverse effects.

In this study, rAAV vector was used to transfer GC into human Gaucher fibroblasts and wild-type C57BL/ $6 \mathrm{~J}$ mice via the hepatic portal vein and tail vein, and the $\mathrm{GC}$ expression and biodistribution were analyzed.

\section{Materials and methods}

\section{Cell culture}

Human fibroblasts were obtained from patients with Gaucher disease after the patients gave informed consent. HEK 293T (human embryonic kidney) cells and fibroblasts derived from patients with Gaucher disease were grown in Dulbecco's modified eagle's medium (Gibco BRL, Grand Island, NY) containing 10\% heatinactivated fetal bovine serum at $37^{\circ} \mathrm{C}$ in a $5 \% \mathrm{CO}_{2}$ incubator.

\section{Construction of rAAV vectors}

The adeno-associated virus (AAV) serotype 2-based vector plasmid pAAV-EF-GC-WPRE, which expresses protein under the control of the human elongation factor $1-\alpha$ promoter, was created as previously described (During et al. 2000) with minor modifications. Fulllength human GC cDNA was subcloned into pAAVEF-EGFP-WPRE-BGHpoly(A) by substitution with EGFP cDNA. Large-scale production of rAAV-EFEGFP vector was carried out in an adenovirus-free system by triple transfection of $293 \mathrm{~T}$ cells with the vector plasmid and two additional plasmids carrying adenoviral helper functions and AAV rep and capsid functions. After $48 \mathrm{~h}$, cells were collected and lysed by freezing and thawing. rAAV-CGA-hAGA vector was purified by $\mathrm{CsCl}$ gradient centrifugation as described (Samulski et al. 1989). The concentration of the viral vector was determined by quantitative PCR by using an ABI 7700 (Perkin-Elmer/Applied Biosystems, Foster City, CA, USA).
Infection of Gaucher fibroblasts and in vivo administration with rAAV vectors

GC-deficient fibroblasts derived from patients with Gaucher disease type I, II, and III were transduced with rAAV-EF-GC or rAAV-EF-EGFP and allowed to grow. In vivo experiments were carried out in $\mathrm{C} 57 \mathrm{BL} / 6 \mathrm{~J}$ mice. All animals were housed in a Korea National Institute of Health mouse facility and were treated according to the Korea Food and Drug Administration and National Institute of Health guidelines for animal care. Sevenweek-old mice were anesthetized with ketamine/xylazine and injected with $1 \times 10^{11}$ particles of rAAV-EF-GC or rAAV-EF-EGFP via the portal or tail vein. The mice were killed at 2, 6, 12, or 20 weeks after injection. The liver, lung, spleen, heart, kidney, brain, stomach, intestine, and bone marrow cells were harvested and stored at $-70^{\circ} \mathrm{C}$ until use. To evaluate liver toxicity, mouse serum was also obtained at day 3 and day 7 and levels of aspartate aminotransferase examined. Histopathological examination was conducted following standard methods. The samples from the mice were embedded in OCT compound and frozen on dry ice. Sections of $7 \mu \mathrm{m}$, stained with hematoxylin and eosin (H\&E), were examined under an optical microscope (Zeiss, Germany).

\section{Assay of GC activity}

Cells and mouse organs were collected and extracted with $50 \mathrm{mM}$ potassium citrate/potassium phosphate (pH 5.6) containing $1.5 \%$ Triton X-100. GC activity was assayed using $4.8 \mathrm{mM}$ 4-methylumbelliferyl glucopyranoside (Koch-Light Lab, Bucks, UK) in $50 \mathrm{mM}$ potassium citrate/potassium phosphate $(\mathrm{pH}$ 5.6) containing $1.5 \%$ sodium taurocholate. After incubation at $37^{\circ} \mathrm{C}$ for $1 \mathrm{~h}$, the reaction was stopped with $0.4 \mathrm{M}$ $\mathrm{NaOH} / 0.4 \mathrm{M}$ glycine. Fluorescence was determined in a microtiter plate fluorometer. GC activity is expressed as nanomoles of $4 \mathrm{MU}$ released per hour per milligram protein for cellular samples and as nanomoles of $4 \mathrm{MU}$ released per hour per milliliter for medium and reported as units (U). One unit is equal to one nanomole of $4 \mathrm{MU}$ released per hour.

Endocytosis of GC secreted by transduced Gaucher fibroblasts

The uptake of GC by GC-deficient fibroblasts derived from patients with Gaucher disease was determined as previously described (Villani et al. 2002). Briefly, Gaucher fibroblasts were plated in $10-\mathrm{cm}$ dishes, transduced at 5,000 MOI of rAAV-EF-GC vector, and allowed to grow for 4 days. Conditioned media were collected, filtered, and placed on a second population of untreated Gaucher fibroblasts with or without $5 \mathrm{mM}$ mannose 6-phosphate. After $96 \mathrm{~h}$, recipient cells were harvested, and $\mathrm{GC}$ activity was determined. 


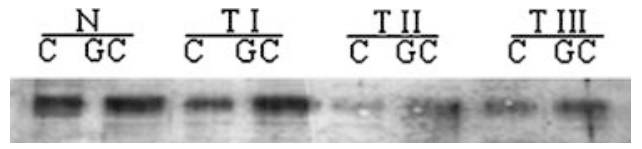

Fig. 1 Immunoblotting of glucocerebrosidase (GC) in fibroblasts from a normal subject and patients with Gaucher disease. GC proteins from fibroblasts transduced with rAAV-EF-GC and untransduced fibroblasts were extracted and immunodetected with a rabbit anti-GC antibody. $N$ normal fibroblast, $T$ I type I Gaucher fibroblasts, T II type II Gaucher fibroblasts, T III type III Gaucher fibroblasts, $C$ untransduced fibroblasts, $G C$ fibroblasts transduced with rAAV-EF-GC

\section{Immunoblotting}

For immunoblotting, transduced and untransduced fibroblasts were homogenized and were centrifuged at $14,000 \mathrm{~g}$ for $20 \mathrm{~min}$ at $4^{\circ} \mathrm{C}$. Proteins were separated by $12 \%$ SDS-PAGE and transferred onto Hybond membranes (Amersham, Buckinghamshire, UK). The blots were then probed with a rabbit-anti-GC polyclonal antibody followed by secondary antibodies conjugated to horseradish peroxidase (Santa Cruz Biotechnology, Inc., Santa Cruz, CA, USA). The blots were developed using chemiluminescent reagents (ECL, Amersham, Germany).

PCR analysis for detection of viral genome

For detection of genome of rAAV-EF-GC in tissue samples, PCR was performed using $0.1-2 \mu \mathrm{g}$ of DNA, EF promoter primer (5'-CGTCCAGGCACCTCGATTAGT- $\left.3^{\prime}\right)$, and human GC primer (5'GGAACTTCTGTTCTGGCTGC-3'). Cycling conditions were $94^{\circ} \mathrm{C}$ for $5 \mathrm{~min}, 35$ cycles of $94^{\circ} \mathrm{C}$ for $30 \mathrm{~s}$, $60^{\circ} \mathrm{C}$ for $30 \mathrm{~s}$, and $72^{\circ} \mathrm{C}$ for $30 \mathrm{~s}$, and final extension at $72^{\circ} \mathrm{C}$ for $7 \mathrm{~min}$. To determine the ratios of viral genome per cell, pAAV-EF-GC-WPRE was serially diluted as a standard template.

\section{Results}

rAAV-EGFP and rAAV-GC expression and activity in vitro

HEK 293T cell and fibroblasts from patients with Gaucher disease were transduced to test the efficiency of the rAAV-EF-EGFP in vitro before the transduction of rAAV-EF-GC to Gaucher patient fibroblasts and mice. Fluorescent microscopic observations showed highly efficient expression of EGFP in cells transduced after 2 days (data not shown). rAAV-EF-EGFP of $1 \times 10^{11}$ particles transduced $50 \%$ of $1 \times 10^{7}$ HEK 293 T cells and about $30 \%$ of $1 \times 10^{6}$ human fibroblasts.

The rAAV-EF-GC vector was introduced into Gaucher fibroblasts. Expression of GC enzymes in Gaucher fibroblasts was evaluated by immunoblotting (Fig. 1). Over-expression of GC was detected in all the transduced Gaucher fibroblasts, and notably, the increased

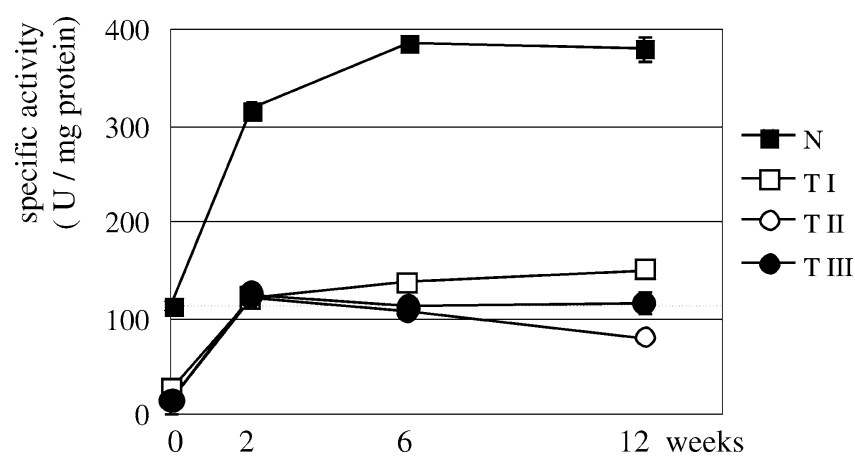

Fig. 2 Glucocerebrosidase (GC) enzyme activities in Gaucher fibroblasts transduced with rAAV-EF-GC vector. GC activities (mean $\pm \mathrm{SD}, n=3$ ) were expressed as units per milligram of protein for cellular samples. GC enzyme activity was analyzed at 2, 6 , and 20 weeks for fibroblasts from all three Gaucher disease types and for normal fibroblasts. Dotted line shows GC activity of untransduced normal fibroblasts. $N$ normal fibroblasts, $T I$ type I Gaucher fibroblasts, T II type II Gaucher fibroblasts, T III type III Gaucher fibroblasts

expression in Gaucher fibroblasts mirrored that in normal fibroblasts.

GC enzyme activity was measured in fibroblasts from all three types of Gaucher disease that were transduced with rAAV-EF-GC at 2, 6, and 12 weeks after transduction (Fig. 2). Two weeks after transduction, normal fibroblasts transduced with rAAV-GC contained substantially higher levels of GC activity (mean $=318.1 \pm 6.6 \mathrm{U} / \mathrm{mg}$ protein) than control untransduced fibroblasts (mean $=113.6 \pm 2.1 \mathrm{U} / \mathrm{mg}$ protein). In type I Gaucher fibroblasts, transduced cells showed 4.6-fold higher enzyme activity (mean $=121.1 \pm 0.2 \mathrm{U} / \mathrm{mg}$ protein) than untransduced cells (mean $=26.4 \pm 1.1 \mathrm{U} / \mathrm{mg}$ protein). Type II and type III transduced cells showed 7.9-fold and 7.8-fold higher activity, respectively (mean $=121.0 \pm 3.9 \mathrm{U} / \mathrm{mg}$ and $124.9 \pm 2.1 \mathrm{U} / \mathrm{mg}$ protein) compared with untransduced cells (mean $=15.4 \pm 0.1 \mathrm{U} / \mathrm{mg}$ and $16.1 \pm 15.1 \mathrm{U} / \mathrm{mg}$ protein). All transduced Gaucher fibroblast showed higher GC activity than untransduced normal fibroblasts at 2 weeks, and this activity persisted for 20 weeks. GC activity was lower in type II Gaucher fibroblasts than in normal fibroblasts at 20 weeks after transduction; however, it was still 5.3-fold higher than in untransduced type II fibroblasts and was $71 \%$ of the activity in untransduced normal fibroblasts. rAAVEF-EGFP viral vector did not show an increase in GC activity (data not shown), and transduction with the rAAV-EF-GC vectors resulted in no cytotoxicity or decrease of cell viability.

Endocytosis of GC secreted by transduced Gaucher fibroblasts by GC-deficient cells

The rAAV-EF-GC vector was introduced into Gaucher fibroblasts. Untreated Gaucher fibroblasts were exposed to conditioned media from transduced Gaucher fibro- 


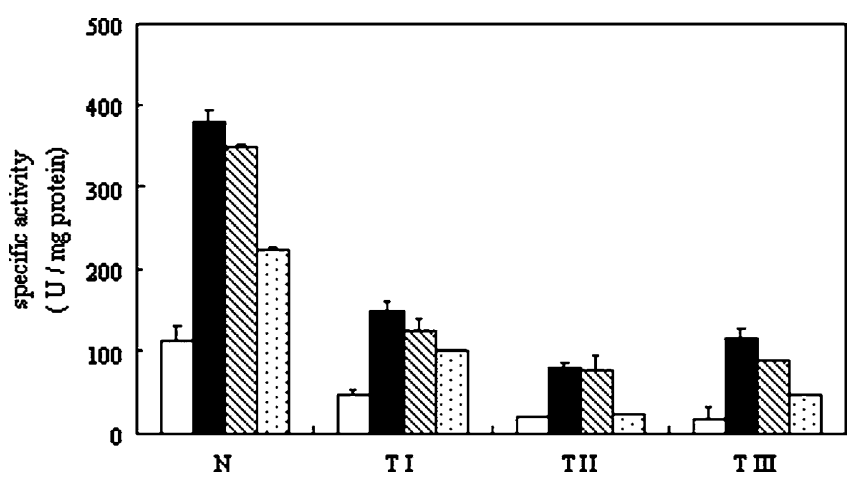

Fig. 3 Endocytosis of glucocerebrosidase (GC) released from Gaucher fibroblasts transduced with rAAV-EF-GC into recipient cell. The GC activities were means $\pm \mathrm{SD}(n=3)$. Open bar untreated cell, black bar transduced with rAAV-EF-GC, hatched bar recipient cells after cultured with media from transduced Gaucher fibroblast, stippled bar recipient cells after cultured with media from transduced Gaucher fibroblast and $5 \mathrm{mM}$ mannose 6-phosphate

blasts. Transduced normal fibroblast in the presence of conditioned media exhibited a GC activity $(348.6 \pm 2.3 \mathrm{U} / \mathrm{mg}$ protein) 3.1 times that found in untransduced cells $(113.6 \pm 16.3 \mathrm{U} / \mathrm{mg}$ protein). The endocytosis of GC was inhibited $53 \%$ of uptake by the addition of $5 \mathrm{mM}$ mannose 6-phosphate $(223.4 \pm 1.3 \mathrm{U} /$ $\mathrm{mg}$ protein) suggesting that the secreted enzyme was transferred to recipient fibroblasts via mannose 6-phosphate receptors. In case of type I Gaucher fibroblast, GC activity of fibroblasts cultured in conditioned media was 2.7 times $(124.6 \pm 15.2 \mathrm{U} / \mathrm{mg}$ protein) that of untransduced cells. In type II and type III, GC activities of fibroblasts cultured in conditioned media were 4.3 times $(77.1 \pm 17.9 \mathrm{U} / \mathrm{mg}$ protein) and 5.5 times $(87.8 \pm 1.1$

Fig. 4a, b Tissue distribution of rAAV-EF-GC genome in transduced mice administered via the a portal vein and $\mathbf{b}$ tail vein. At 6 weeks after infusion, mice organs were separated and the DNA isolated. Using EF-promoter primer and human glucocerebrosidase (GC) primer, only virus vector-mediated genes were amplified. The ratios of viral genome per number of mouse cells were calculated with the right lanes of serially diluted pAAV-EFGC-WPRE. Amounts of plasmid are presented as femtograms. $C$ untransduced mice organ, $G C$ mice organ transduced with rAAV-EF-GC
$\mathrm{U} / \mathrm{mg}$ protein) that of untransduced cells, respectively (Fig. 3).

In vivo expression of $\mathrm{GC}$ after hepatic portal vein and tail vein delivery of the virus

To demonstrate a therapeutic effect of rAAV, rAAVEF-GC was injected intravenously into wild-type $\mathrm{C} 57 \mathrm{BL} / 6 \mathrm{~J}$ mice via the portal vein and tail vein. In all mice, no gross abnormalities were noted in any internal organ or at the injection site. Their behavior did not differ from that of untreated mice. No lymphocytic infiltration or other sign of inflammation was seen in any of the organs examined by inspection of H\&E-stained sections (data not shown).

To determine the distribution of the rAAV-EF-GC vector, we isolated DNA from various tissues of mice 6 weeks after transduction with rAAV-EF-GC and determined the viral sequence using PCR. Viral sequences were detected in the liver and spleen after portal vein infusion (Fig. 4a) and the liver, spleen, heart, lung, kidney, and stomach after tail vein infusion (Fig. 4b). The ratio between the number of viral genome copies and cell numbers was calculated according to plasmid standard. After portal vein infusion, the ratio was approximately one copy per $10^{2}$ hepatocytes. After tail vein infusion, the ratio ranged from one copy per $10^{2}$ cells (liver), $10^{3}$ cells (spleen and heart) and $10^{4}$ cells (lung, kidney, and stomach). These ratios are in good agreement with GC activities at 6 weeks after infusion.

GC activity was determined in mouse serum and tissues at 2, 6, 12, and 20 weeks after infusion of rAAVEF-GC via the portal vein (Table 1). The average GC activity in the liver of untreated wild-type mice liver was $139.8 \pm 8.9 \mathrm{U} / \mathrm{mg}$ protein. Mice that received rAAVEF-GC vector by the portal vein showed liver activity of $224.5 \pm 19.7 \mathrm{U} / \mathrm{mg}$ protein $(1.6$ times that of untreated mice) at 2 weeks and $275.2 \pm 55.5 \mathrm{U} / \mathrm{mg}$ protein $(2.0$ times that of untreated mice) at 6 weeks after treatment. Increased GC activity persisted over 20 weeks $(208.6 \pm 24.4 \mathrm{U} / \mathrm{mg}$ protein, 1.5 times that of untreated mice). In spleen and lung, GC activity was significantly higher in the treated than in the untreated mice. In other organs, no significant increase of GC activity was ob-

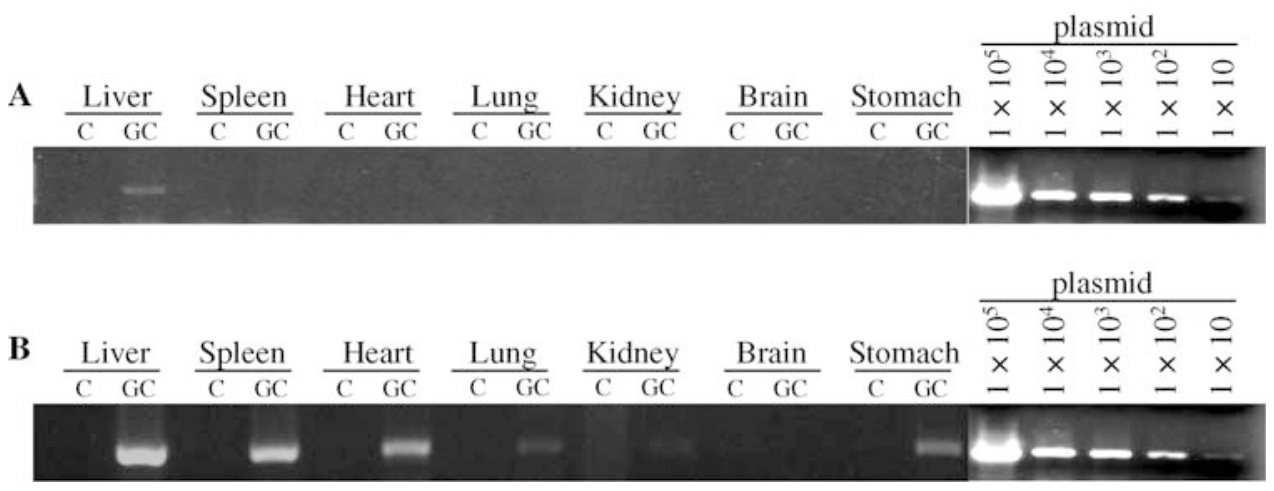


served. rAAV-EF-EGFP was used as a control vector. To determine the GC expression of rAAV-EF-EGFP, we isolated various tissues (liver, spleen, heart, lung, kidney, brain) of transduced mice. GC activity was determined at 6 weeks after viral infusion via the portal vein. GC activity was not increased in mice treated with rAAV-EF-EGFP compared with activity in untreated mice (data not shown).

GC activity was determined in mouse serum and tissues at 2, 6, and 20 weeks after infusion of rAAVEF-GC via the tail vein (Table 2). GC activity in livers of mice that received rAAV-EF-GC vector was $221.8 \pm 10.1 \mathrm{U} / \mathrm{mg}$ protein at 2 weeks after treatment. This activity was 1.6 times that of untreated mice. At 6 weeks after infusion, GC activity in the liver was increased to 1.7 times that of untreated mice with this maintained to 20 weeks (1.4 times that of untreated mice). In the spleen, there was increased GC activity at 6 weeks (1.4 times that of untreated mice) and at 20 weeks (1.4 times that of untreated mice) after infusion. In the lung, GC activity was increased significantly at 6 weeks after treatment, 1.3 times that of untreated mice.

\section{Discussion}

Gaucher disease is a potential candidate for gene therapy. Genetically modified cells that express GC have been supposed to provide this essential housekeeping enzyme and cross-correct enzyme-deficient bystander cells. However, previous bone marrow transplantation studies for Gaucher disease did not bring positive prospect on this cross-correction effect. In human chimeras after bone marrow transplantation, there was only partial correction (Chan et al. 1994; Ringdén et al. 1995), and in murine chimeras, there was no evidence of mutual correction (Beutler et al. 2002). Furthermore, previous gene therapy studies for Gaucher disease using retrovirus vectors have shown little progress because of low transduction efficiencies and limitations of application (Novelli and Barranger 2001).

Unlike many lysosomal enzymes, the mannose lectin on cell membranes rather than the mannose 6-phosphate lectin appears to be primarily involved in the endocytosis of GC (Doebber et al. 1982). GC obtained from human placental tissue or $\mathrm{CHO}$ cells does not have mannose 6-phosphate (Furbish et al. 1981; Takasaki et al. 1984). This result suggests that posttranscriptional glycosylation of GC can vary depending on the type of cell (Erickson et al. 1985). In the present experiments, the ratios of transgene per liver cells was about $1 \times 10^{-2}$, with GC activity increased 1.9 fold in the transduced mice liver compared with that of untreated mice. This means that continuously expressed GC in transduced cells can be secreted to bystander cells that preserve this received enzyme. There is currently no direct evidence that most liver cells transduced with rAAV vector have transduced GC; however, in vitro assay of endocytosis shows that transduced fibroblasts secret GC, and

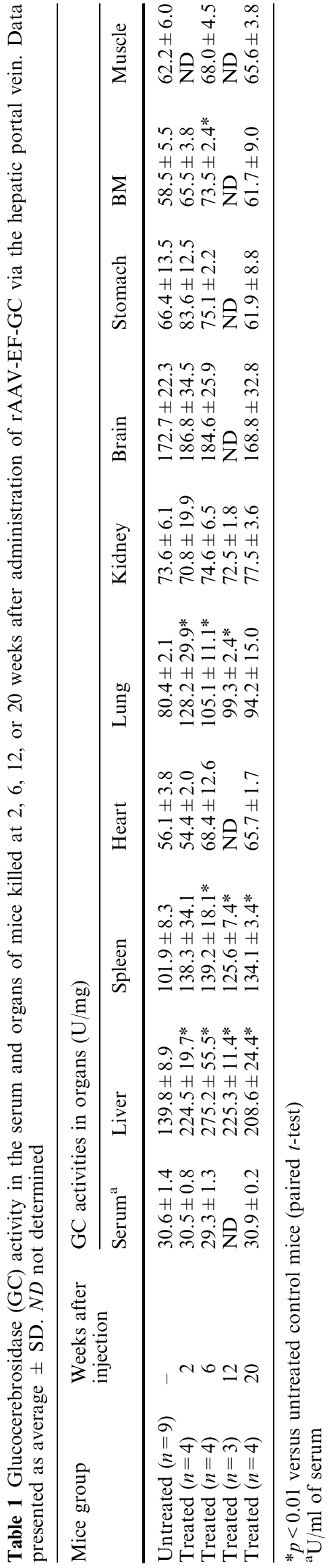


neighboring cells take this enzyme up (Fig. 3). Competition studies revealed that the addition of mannose 6phosphate to the culture medium partially inhibited the uptake of secreted GC. We therefore deduce that GC secreted from transduced fibroblasts has some mannose 6-phosphate residues. Furthermore, we observed the secretion of expressed GC and reuptake by neighboring tissues when we injected rAAV-EF-GC into the liver via the portal vein. Transgene was expressed in the liver only (Fig. 4a), but GC activities were significantly elevated in the spleen, lung, and bone marrow as well as in the liver (Table 1). This phenomenon was also demonstrated in experiments using a recombinant lentivirus vector (Kim et al. 2004).

In a previous study, we demonstrated that a recombinant lentivirus can mediate efficient gene transfer for Gaucher disease (Kim et al. 2004). Enzyme activity of mice livers that had been transduced with recombinant lentivirus were increased 3.5 fold at 2 weeks after hepatic portal vein administration and 1.9 fold at 8 weeks after tail vein infusion. Although GC activity in tissues transduced by rAAV vector infusion was lower than activity following recombinant lentivirus vectormediated gene transfer, these in vivo activities show the feasibility of rAAV-EF-GC in gene therapy. Specifically, for patients with Gaucher disease, raising GC activity to a level greater than $40 \%$ of normal would bring them into the heterozygous range, so they would be symptomfree (Beutler and Grabowski 2001).

Instead of using adenovirus or lentivirus vector, using rAAV vector for gene therapy has many advantages. AAV can transduce both dividing and nondividing cells over a long period without considerable safety issues (Nakai et al. 2000). It has been widely used for gene therapy studies in inherited diseases such as hemophilia B (Herzog et al. 1999), muscular dystrophy (Wang et al. 2000), and Fabry disease (Jung et al. 2001) with promising results.

It is also important to determine whether enzymes expressed by recombinant viral vector-mediated gene transfer could localize to the Kupffer cells. Marshall et al. showed that GC produced by adenovirus vector-mediated gene transfer has the ability to localize to Kupffer cells and exhibits a longer half-life than the modified enzyme (Marshall et al. 2002). The GC expressed by rAAVmediated gene transfer could be a useful therapeutic approach for patients with Gaucher disease.

In this study, we demonstrated that rAAV-mediated gene transfer successfully delivered the human GC gene into human fibroblasts and mice and induced high levels of GC expression over 12 weeks in vitro and 20 weeks in vivo. Although we observed stable expression over a 12week in vitro study, the mechanism of stable expression of transduced rAAV was unclear. Nakai et al. reported that transduced rAAV existed as not-integrated extrachromosomal form in the liver (Nakai et al. 2001). However, the rAAV genome also preferentially integrated into chromosomal DNA (Nakai et al. 2003). Further studies should be conducted for elucidating 
stable expression of rAAV vector in fibroblast to determine whether or not this phenomenon comes from integration. AAV serotype 2 vector was used in this study. About nine serotypes have been identified in AAV up until now. Each AAV serotype has different tropism. Since the primary therapeutic targets of type 1 Gaucher disease are the liver and spleen, AAV serotype 8 would be getting the highest therapeutic effect for Gaucher patients because AAV serotype 8 vector expressed stronger than any other serotype AAV vectors in the liver (Sarkar et al. 2004). Pseudotyped AAV vector $2 / 8$, AAV 2 genome packaged into AAV 8 capsid, could be considered to obtain highest expression levels of GC in the liver.

Evaluation of in vivo approaches to Gaucher disease therapy has been hindered by the lack of a viable animal model (Tybulewiez et al. 1992; Liu et al. 1998). However, in this study, wild-type C57BL/6J mice showed an increase of GC activity that was within the therapeutic range. The generation of a viable mouse model of Gaucher disease has been reported very recently $(\mathrm{Xu}$ et al. 2003); this mouse model will likely be useful for demonstration of inhibited accumulation of glucocerebroside by rAAV-EF-GC vector-mediated gene therapy.

Acknowledgements The authors would like to thank Genzyme Corporation for the gifts of the rabbit anti-GC monoclonal and polyclonal antibodies. This work was supported by a grant (01PJ10-PG6-01GN15-0001) of the Korea 21 R\&D Project, Ministry of Health and Welfare, Republic of Korea.

\section{References}

Barton NW, Furbish FS, Murray GJ, Garfield M, Brady RO (1990) Therapeutic response to intravenous infusion of glucocerebrosidase in a patient with Gaucher disease. Proc Natl Acad Sci USA 87:1913-1916

Barton NW, Brady RO, Dambrosia JM, Di Bisceglie AM, Doppelt SH, Hill SC, Mankin HJ, Murray GJ, Parker RI, Argoff CE, Grewal RP, Yu KT (1991) Replacement therapy for inherited enzyme deficiency-macrophage-targeted glucocerebrosidase for Gaucher disease. N Engl J Med 324:1464-1470

Beutler E, Grabowski GA (2001) Gaucher disease. In: Scriver CR, Beaudet AL, Sly WS, Valle D (eds) The metabolic and molecular bases of inherited disease, 8th edn. McGraw-Hill, New York, pp 3635-3668

Beutler E, West C, Torbett BE, Deguchi H (2002) A chimeric mouse model of Gaucher disease. Mol Med 8:247-250

Brady RO, Kanfer JN, Bradley RM, Shapiro D (1966) Demonstration of a deficiency of glucocerebroside-cleaving enzyme in Gaucher's disease. J Clin Invest 45:1112-1115

Brady RO, Barton NW, Grabowski GA (1993) The role of neurogenetics in Gaucher disease. Arch Neurol 50:1212-1224

Chan KW, Wong LTK, Applegarth D, Davidson AGF (1994) Bone marrow transplantation in Gaucher's disease: effect of mixed chimeric state. Bone Marrow Transplant 14:327-330

Cox T, Lachmann R, Hollak C, Aerts J, van Weely S, Hrebicek M, Platt F, Butters T, Dwek R, Moyses C, Gow I, Elstein D, Zimran AT (2000) Novel oral treatment of Gaucher disease with $N$-butyldeoxynojirimycin (OGT 918) to decrease substrate biosynthesis. Lancet 355:1481-1485

Dahms NM, Lobel P, Kornfeld S (1989) Mannose 6-phosphate receptors and lysosomal enzyme targeting. J Biol Chem 264:12115-12118
Doebber TW, Wu MS, Bugianesi RL, Ponpipom MM, Furbish FS, Barranger JA, Brady RO, Shen TY (1982) Enhanced macrophage uptake of synthetically glycosylated human placental beta-glucocerebrosidase. J Biol Chem 257:2193-2199

During MJ, Symes CW, Lawlor PA, Lin J, Dunning J, Fitzsimons HL, Poulsen D, Leone P, Xu R, Dicker BL, Lipski J, Young D (2000) An oral vaccine against NMDAR1 with efficacy in experimental stroke and epilepsy. Science 287:1453-1460

Erickson AH, Ginns EI, Barranger JA (1985) Biosynthesis of the lysosomal enzyme glucocerebrosidase. J Biol Chem 260:1431914324

von Figura K, Hasilik A (1986) Lysosomal enzymes and their receptors. Annu Rev Biochem 55:167-193

Furbish FS, Steer CJ, Krett NL, Barranger JA (1981) Uptake and distribution of placental glucocerebrosidase in rat hepatic cells and effects of sequential deglycosylation. Biochim Biophys Acta 673:425-434

Grabowski GA, Barton NW, Pastores G, Dambrosia JM, Banerjee TK, Mckee MA, Parker C, Schiffmann R, Hill SC, Brady RO (1995) Enzyme therapy in Gaucher disease Type 1: comparative efficacy of mannose-terminated glucocerebrosidase from natural and recombinant sources. Ann Intern Med 122:33-39

Herzog RW, Yang EY, Couto LB, Hagstrom JN, Elwell D, Fields PA, Burton M, Bellinger DA, Read MS, Brinkhous KM, Podsakoff GM, Nichols TC, Kurtzman GJ, High KA (1999) Longterm correction of canine hemophilia B by gene transfer of blood coagulation factor IX mediated by adeno-associated viral vector. Nat Med 5:56-63

Jung SC, Han IP, Limaye A, Xu R, Gelderman MP, Zerfas P, Tirumalai K, Murray GJ, During MJ, Brady RO, Qasba P (2001) Adeno-associated viral vector-mediated gene transfer results in long-term enzymatic and functional correction in multiple organs of Fabry mice. Proc Natl Acad Sci USA 98:2676-2681

Kim EY, Hong YB, Lai Z, Kim HJ, Cho YH, Brady RO, Jung SC (2004) Expression and secretion of human glucocerebrosidase mediated by recombinant lentivirus vectors in vitro and in vivo: implications for gene therapy of Gaucher disease. Biochem Biophys Res Commun 318:381-390

Kornfeld S, Mellman I (1989) The biogenesis of lysosomes. Annu Rev Cell Biol 5:483-525

Liu Y, Suzuki K, Reed JD, Grinberg A, Westphal H, Hoffmann A, Döring T, Sandhoff K, Proia RL (1998) Mice with type 2 and 3 Gaucher disease point mutations generated by a single insertion mutagenesis procedure (SIMP). Proc Natl Acad Sci USA 95:2503-2508

Marshall J, McEachern KA, Cavanagh JA, Nietupski JB, Budzinski TL, Ziegler RJ, Yew NS, Sullivan J, Scaria A, Rooijen N, Barranger JA, Cheng SH (2002) Demonstration of feasibility of in vivo gene therapy for Gaucher disease using a chemically induced mouse model. Mol Ther 6:179-189

Nakai H, Storm TA, Kay MA (2000) Recruitment of single-stranded recombinant adeno-associated virus vector genomes and intermolecular recombination are responsible for stable transduction of liver in vivo. J Virol 74:9451-9463

Nakai H, Yant SR, Storm TA, Fuess S, Meuse L, Kay MA (2001) Extrachromosomal recombinant adeno-associated virus vector genomes are primarily responsible for stable liver transduction in vivo. J Virol 75:6969-6976

Nakai H, Montini E, Fuess S, Storm TA, Grompe M, Kay MA (2003) AAV serotype 2 vectors preferentially integrate into active genes in mice. Nat Genet 34:297-302

Neufeld EF (1991) Lysosomal storage diseases. Annu Rev Biochem 60:257-280

Novelli EM, Barranger JA (2001) Gene therapy for lysosomal storage disorders. Expert Opin Biol Ther 1:857-867

Ringdén O, Groth CG, Erikson A, Granqvist S, Månsson JE, Sparrelid E (1995) Ten years' experience of bone marrow transplantation for Gaucher disease. Transplantation 59:864 870

Samulski RJ, Chang LS, Shenk T (1989) Helper-free stocks of recombinant adeno-associated viruses: normal integration does not require viral gene expression. J Virol 63:3822-3828 
Sarkar R, Tetreault R, Gao G, Wang L, Bell P, Chandler R, Wilson JM, Kazazian HH Jr (2004) Total correction of hemophilia A mice with canine FVIII using an AAV 8 serotype. Blood 103:1253-1260

Takasaki S, Murray GJ, Furbish FS, Brady RO, Barranger JA, Kobata A (1984) Structure of the $N$-asparagine-linked oligosaccharide units of human placental beta-glucocerebrosidase. J Biol Chem 259:10112-10117

Tybulewiez VLJ, Trembly ML, LaMarea ME, Willemsen P, Stubblefield BK, Winfield S, Zablocka B, Sidransky E, Martin BM, Huang SP, Mintzer KN, Westphal H, Mulligan RO, Ginns EI (1992) Animal model of Gaucher's disease from targeted disruption of the mouse glucocerebrosidase gene. Nature $357: 407-410$
Villani GRD, Follenzi A, Vanacore B, Domenico CD, Naldini L, Natale PD (2002) Correction of mucopolysaccharidosis type IIIb fibroblasts by lentivirus vector-mediated gene transfer. Biochem J 364:747-753

Wang B, Li J, Xiao X (2000) Adeno-associated virus vector carrying human minidystrophin genes effectively ameliorates muscular dystrophy in mdx mouse model. Proc Natl Acad Sci USA 97:13714-13719

Xu YH, Quinn B, Witte D, Grabowski GA (2003) Viable mouse models of acid beta-glucosidase deficiency: the defect in Gaucher disease. Am J Pathol 163:2093-2101 